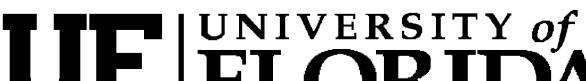 FLORIDA \\ IFAS Extension
}

HS1151

\section{'Florida Radiance' Strawberry ${ }^{1}$}

\section{C.K. Chandler, B.M. Santos, and N.A. Peres ${ }^{2}$ \\ Origin and Description}

'Strawberry Festival' (Chandler et al., 2000) is currently the primary strawberry (Fragaria $x$ ananassa Duch.) cultivar in Florida, and an important cultivar in other winter and early spring production areas around the world. However, in west Central Florida, this cultivar produces relatively low yields early in the season (late November/early December), and during the second half of the main production period (starting in late February) it tends to produce fruit of marginal size. Thus, there is a need for a strawberry cultivar to complement 'Strawberry Festival'.

'Florida Radiance' originated from a 2001 cross between 'Winter Dawn' and FL 99-35. 'Winter Dawn', a 2005 release from University of Florida strawberry breeding program, was used as a parent because of its high early-season yield potential and ability to produce large primary and secondary fruit. FL 99-35 was used as a parent because of its ability to produce firm, attractive fruit. 'Florida Radiance' is a short day cultivar. It has a more open-plant habit than 'Strawberry Festival' which, along with fruit that are attached to long pedicels, makes the plant easy to harvest (Fig. 1). In studies conducted in west central
Florida, 'Florida Radiance' had a mean fruit weight of between 21 and $23 \mathrm{~g}$, compared to between 18 and $21 \mathrm{~g}$ for 'Strawberry Festival'. Fruit are mostly medium conic in shape, with some early season fruit being elongated and some primary fruit being asymmetrical (Fig. 2). The achenes are slightly sunken, giving the fruit a smooth appearance. External fruit color is a glossy bright to dark red (depending on maturity). 'Florida Radiance' fruit are not significantly different in lightness than 'Strawberry Festival' fruit. The internal color of 'Florida Radiance' fruit is a warm red and the calyx is generally medium to large in size and attractive. Fruit of 'Florida Radiance' are firm and juicy.

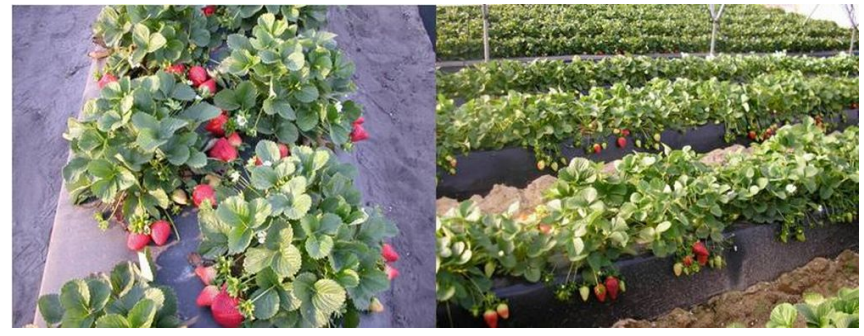

Fig. 1.. Plants of 'Florida Radiance' strawberry grown on polyethylene mulch in Florida (left), and Spain (right).

1. This document is HS1151, one of a series of the Horticultural Sciences Department, Florida Cooperative Extension Service, Institute of Food and Agricultural Sciences, University of Florida. Original publication date, December 2008. Visit the EDIS Web site at http://edis.ifas.ufl.edu.

2. C.K. Chandler, professor, and B.M. Santos, assistant professor, Horticultural Sciences Department, and N.A. Peres, assistant professor, Plant Pathology Department, Gulf Coast Research and Education Center, Florida Cooperative Extension Service, Institute of Food and Agricultural Sciences, University of Florida, Gainesville.

The Institute of Food and Agricultural Sciences (IFAS) is an Equal Opportunity Institution authorized to provide research, educational information and other services only to individuals and institutions that function with non-discrimination with respect to race, creed, color, religion, age, disability, sex, sexual orientation, marital status, national origin, political opinions or affiliations. U.S. Department of Agriculture, Cooperative Extension Service, University of Florida, IFAS, Florida A. \& M. University Cooperative Extension Program, and Boards of County Commissioners Cooperating. Larry Arrington, Dean 


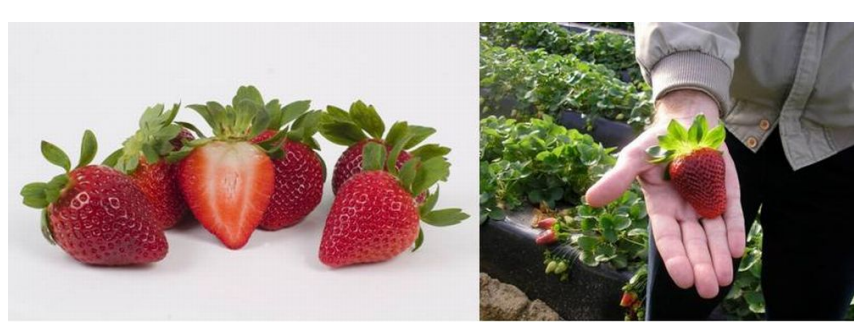

Fig. 2.. External appearance and internal section of 'Florida Radiance' srawberry.

\section{Performance}

Yields of 'Florida Radiance' were complementary to those of 'Strawberry Festival' during recent studies. 'Florida Radiance' had higher production than 'Strawberry Festival' in February, while 'Strawberry Festival' had higher production than 'Florida Radiance' in January. 'Florida Radiance' is moderately resistant to the two most serious disease problems on strawberry in Florida: Botrytis fruit rot (caused by Botrytis cinerea) and anthracnose fruit rot (caused by Colletotrichum acutatum). In an unsprayed trial during the 2007-08 season, only $3 \%$ of the 'Florida Radiance' fruit harvested from mid-February to mid-March showed symptoms of anthracnose fruit rot, compared to 53\% for 'Treasure', the susceptible control (N. Peres, unpublished data). But 'Florida Radiance' is susceptible to crown rots (C.K. Chandler, personal observations), which are most likely caused by $C$. gloeosporioides or Phytophthora spp.

'Florida Radiance' strawberry has consistently produced high early-season yields, and has maintained good fruit size throughout the main production period in plots at the University of Florida, and on several commercial farms in west-central Florida and southwest Spain. It is recommended for trial in areas with mild winter climates. This strawberry genotype is named 'Florida Radiance' because of the attractive luster of its fruit.

\section{Literature Cited}

Chandler, C.K., D.E. Legard, D.D. Dunigan, T.E. Crocker, and C.A. Sims. 2000. 'Strawberry Festival' Strawberry. HortScience 35:1366-1367.

\section{Availability}

Information on nurseries licensed to propagate 'Florida Radiance' can be obtained from the Florida Strawberry Growers Association (http://flastrawberry.com) or Ekland Marketing Company of California, Inc. (http://www.emcocal.com). 